\title{
NEW RADIOCARBON AGES OF LUZIA WOMAN, LAPA VERMELHA IV SITE, LAGOA SANTA, MINAS GERAIS, BRAZIL
}

\author{
Michel Fontugne \\ Laboratoire des Sciences du Climat et de l'Environnement (UMR8212 CNRS/CEA/UVSQ), Domaine du CNRS, 91198 \\ Gif-sur-Yvette Cedex, France. Email: Michel.Fontugne@lsce.ipsl.fr.
}

\begin{abstract}
Luzia woman is considered one of the oldest Paleoindian skeletons found in the Americas. Luzia was found at the Lapa Vermelha IV site (Lagoa Santa, Minas Gerais, Brazil) in 1975 by the archaeologist Annette Laming-Emperaire (1917-1977) who sent to the Gif laboratory charcoals collected in the vicinity of the skeleton for radiocarbon dating. Twentynine charcoal samples were dated from different levels of the stratigraphy of the cave (Délibrias et al. 1986). Recently, new charcoal samples were discovered within Laming-Emperaire's correspondence and were subsequently dated by the Saclay AMS laboratory. The new results confirm the age of Luzia; however, the ages correspond to the younger part of the interval: charcoals found near Luzia's skull give an age of $10,030 \pm 60{ }^{14} \mathrm{C}$ yr BP $(11,243-11,710$ cal BP).
\end{abstract}

\section{INTRODUCTION}

For at least 50 years, the question of when the first humans arrived in the New World has been debated. Archaeological excavations have uncovered numerous old human settlements but few human bone remains for the late Pleistocene were found. Peter Wilhelm Lund $(1842,1844)$ first discovered human skeletons in the vicinity of Pleistocene extinct mammals remains in the Lagoa Santa region (Minas Gerais), suggesting an ancient human presence in the Americas. Despite the importance of these findings, it was more than a century later that excavations began again. In the same region, Hurt (1960) and Hurt and Blasi (1969) confirmed the evidence of old settlements at Cerca Grande (between 9 and $10 \mathrm{ka}$ BP but no fossil bones were found during these investigations). Between 1973 and 1976, a French/Brazilian team supervised by Annette Laming-Emperaire excavated the large rockshelter Lapa Vermelha IV. Few artifacts were found, but the discovery of fossil mammal remains and bones belonging to a woman revived interest in this site. Numerous radiocarbon dates were obtained (Délibrias et al. 1986) bracketing the age of the skeleton between 10,200 \pm 220 and $12,960 \pm 300{ }^{14} \mathrm{C}$ yr BP. The unexpected death of Laming-Emperaire in 1977 brought the study to a halt again.

The skeleton belongs to a woman aged $20-25 \mathrm{yr}$, measuring $1.5 \mathrm{~m}$ and was called Luzia. At the time, she was the oldest known American but was joined later by other candidates for the title. A direct dating of Luzia's bones was attempted, but unfortunately no collagen was preserved and the organic residue (mainly the humic acids generally considered a contaminant) returned an age of $9330 \pm$ 60 BP (Beta 84439) (Prous and Fogaça 1999; Araujo et al. 2005). The true age of the skeleton was believed to be older.

Although Laming-Emperaire believed that the human skull had been found in situ, Mello e Alvim (1977) pointed out that the bones of the skeleton are intrusive, since the skull, mandible, left tibia, and femur were found at 12.9, 10.45, 11.5, and between 10 and $10.2 \mathrm{~m}$ depth, respectively (Figure 2 from Laming-Emperaire et al. 1975). However, André Prous (in Hurt 1986) reported that the human skull and remains of a giant sloth (Scelidotherium) dated to $9580 \pm 200{ }^{14} \mathrm{C}$ yr BP were both colored red, indicating that they belong to the same stratigraphic unit. All these uncertainties raised some doubts about the antiquity of Luzia, especially as detailed craniometric analyses suggested an African and/or Australian origin for this ancient population of the Lagoa Santa area (Neves et al. 1999). This interpretation is controversial; however, some new data about the chronology of the archaeological levels are likely to frame this new debate. 


\section{Fontugne}

Recently, a search in the Gif laboratory archives led to the discovery of several mail envelopes sent by Laming-Emperaire containing a few mg of charcoals found near the Luzia skeleton. We present here these new dating results.

\section{MATERIAL AND METHODS}

The rockshelter of Lapa Vermelha IV $\left(19^{\circ} 40^{\prime} \mathrm{S}, 43^{\circ} 54^{\prime} \mathrm{W}\right)$ is located in Pedro Leopoldo county, Lagoa Santa region (Minas Gerais, central Brazil), and is part of a karstic complex of caves, shelters, and underground water channels (Laming-Emperaire et al. 1975). Descriptions and the results obtained from this site were published by Laming-Emperaire (1976, 1979), Laming-Emperaire et al. (1975), and Prous (1980).

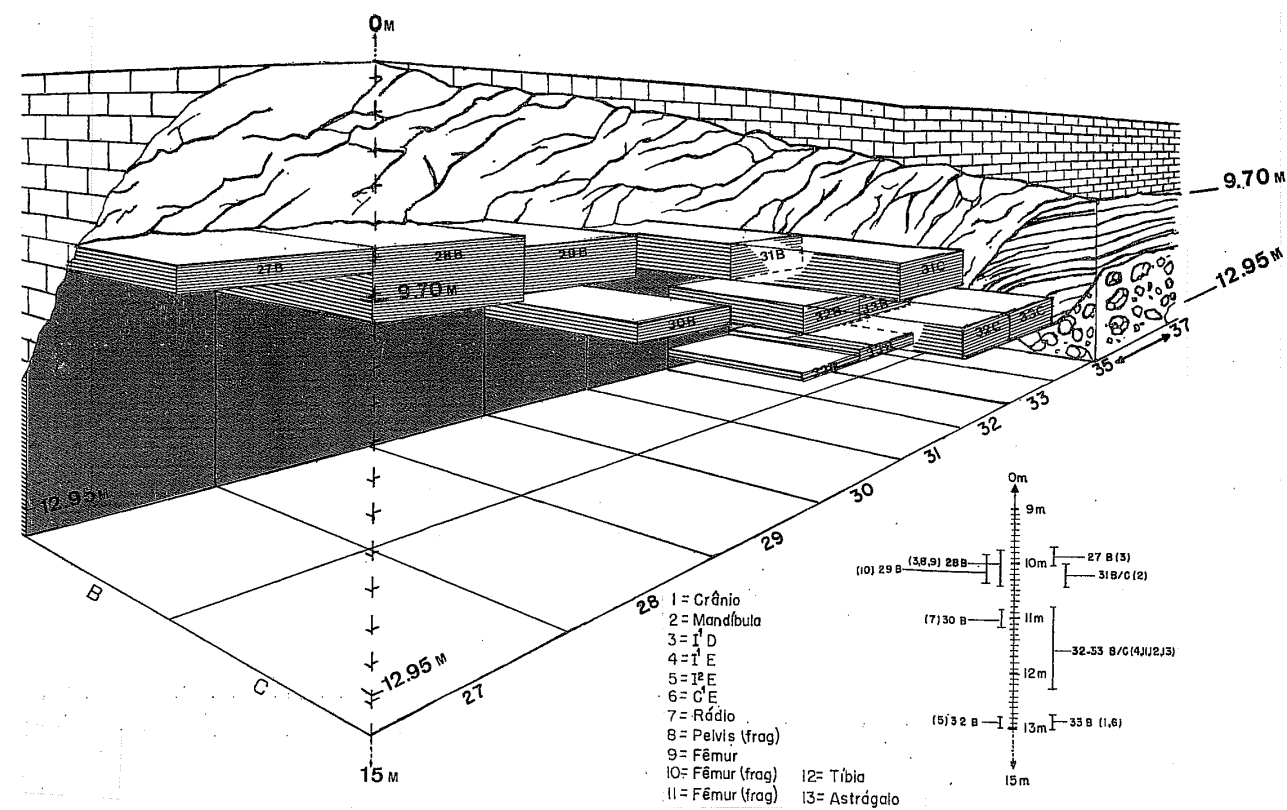

Figure 1 Schematic representation of the excavation of Lapa Vermelha Cave with the location of human bones marked (from Laming-Emperaire et al. 1975). The depths of the human remains in sector 30-33B are given in the lower part of the figure. The locations of the new samples are listed in Table 1.

Recently, James Feathers of the University of Washington asked for information concerning the Lapa Vermelha IV dates. This led to searching the Gif laboratory archives and the discovery of these forgotten samples in several envelopes mailed by Laming-Emperaire containing a few $\mathrm{mg}$ of charcoals certainly ignored at that time due to their quantity being far too low for beta counting. Four samples from the red sediment level were dated; their description, depth, and location within the stratigraphy are reported in Table 1. Sample reference 67 was collected near the skull in unit 33B.

Sample preparation followed the standard acid-alkali-acid (AAA) treatment: $1 \mathrm{M} \mathrm{HCl}, 0.1 \mathrm{M}$ then $1 \mathrm{M} \mathrm{NaOH}$, and $0.1 \mathrm{M}$ and $1 \mathrm{M} \mathrm{HCl}$. All treatments were performed at room temperature either in an ultrasonic bath or under agitation. Rinsing with ultrapure water followed each step. About $1 \mathrm{mg}$ of clean charcoal was then sealed in a quartz tube under vacuum with an excess of copper oxide and silver wire. Tubes were placed in an oven at $840^{\circ} \mathrm{C}$ for $5 \mathrm{hr}$ to transform the organic matter into $\mathrm{CO}_{2}$. The evolved $\mathrm{CO}_{2}$ was then reduced to obtain graphite targets prepared following the method 
described by Arnold et al. (1987, 1989) and Hatte et al. (2003). Analyses were performed at the French National AMS facilities (LMC14) and results are expressed as conventional ages following Stuiver and Polach (1977). Calibrated ages are expressed as cal BP with a confidence level of $95.4 \%$ $(2 \sigma)$ following Stuiver and Reimer (1993) and Reimer et al. (2004).

\section{RESULTS AND DISCUSSION}

Results are reported in Table 1 and range from $3300 \pm 30$ to $11,100 \pm 60{ }^{14} \mathrm{C}$ yr BP, in reasonable agreement with the stratigraphy. Sample 42 from units 27 to 29 at $11.7 \mathrm{~m}$ depth and sample 51 from units 32-33 at $12.6 \mathrm{~m}$ depth present ages similar to those obtained in the same sector of the excavations by Délibrias et al. (1986), for levels D to $\mathrm{F}$ and unit 32B (Gif-3907: $5400 \pm 500{ }^{14} \mathrm{C} \mathrm{BP}$ ), respectively. Sample $91\left(11,100 \pm 60{ }^{14} \mathrm{C} \mathrm{BP}\right)$ is significantly younger than sample 121 collected in the levels just below (Gif-3905: 15,300 $\pm 400{ }^{14} \mathrm{C} \mathrm{BP}$ ). These new results integrate well in the series published by Délibrias et al. (1986) and suggest that the stratigraphy of the deposits, in several sedimentary units of the cave, was disturbed or reworked as suggested by Hurt (1986) and Mello e Alvim (1977). Sample 67 of charcoal surrounding Luzia's skull gave an age of 10,030 $\pm 60{ }^{14} \mathrm{C} \mathrm{BP}$ $[11,243-11,710 \mathrm{cal} \mathrm{BP}$, confidence level $95.4 \%]$ and confirms the antiquity of the skull as already supposed by the date of the bone organic fraction. Nevertheless, the age corresponds to the youngest estimates proposed for Luzia, who remains the oldest Brazilian paleoindian.

Table 1 References and ${ }^{14} \mathrm{C}$ ages of the charcoal samples. $\delta^{13} \mathrm{C}$ is measured by AMS and is not representative of the carbon isotopic composition of the charcoal since it includes carbon isotope fractionation due to target preparation and fractionation within beams in the AMS. The $\delta^{13} \mathrm{C}$ values provided by the Saclay facilities differ generally by $\pm 3 \%$ from the IRMS $\delta^{13} \mathrm{C}$ values ranging between $-25 \%$ and $-30 \%$ for tropical forest wood.

\begin{tabular}{|c|c|c|c|c|c|c|}
\hline Lab code & $\begin{array}{l}\text { Refer- } \\
\text { ence }\end{array}$ & Location & $\begin{array}{l}\text { Depth } \\
(\mathrm{m})\end{array}$ & Comments & $\begin{array}{l}{ }^{14} \mathrm{C} \text { age } \\
\mathrm{BP}\end{array}$ & $\begin{array}{l}\delta^{13} \mathrm{C} \\
(\%)\end{array}$ \\
\hline SacA17001/Gif-12419 & 42 & $\begin{array}{l}\text { LV-IV } \\
27-28-29 A B \\
17 / 04 / 75\end{array}$ & 11.70 & Red sediment & $3320 \pm 30$ & -26.7 \\
\hline SacA17002/Gif-12420 & 51 & $\begin{array}{l}\text { LV-IV 32-33B } \\
\text { 17/04/75 } \\
\text { Code F26-28 }\end{array}$ & $12.60-12.70$ & $\begin{array}{l}\text { Red sediment near } \\
\text { the skull }\end{array}$ & $4075 \pm 35$ & -27.1 \\
\hline SacA17000/Gif-12418 & 67 & $\begin{array}{l}\text { LV-IV/33B } \\
18 / 04 / 75\end{array}$ & $12.80-12.95$ & $\begin{array}{l}\text { Red sediment, } \\
\text { charcoal surround- } \\
\text { ing the skull }\end{array}$ & $10,030 \pm 60$ & -31.0 \\
\hline SacA17003/Gif-12421 & 91 & $\begin{array}{l}\text { LV-IV 32-33B } \\
\text { 17/04/75 } \\
\text { F26-28 }\end{array}$ & $13.15-13.55$ & $\begin{array}{l}\text { Red sediment, sim- } \\
\text { ilar to Gif-3905 }\end{array}$ & $11,100 \pm 60$ & -21.2 \\
\hline $\begin{array}{l}\text { Gif-3905 } \\
\text { Délibrias et al. } 1986\end{array}$ & 121 & $\begin{array}{l}\text { Unit 32-33 } \\
\text { L.V.IV } 75.121\end{array}$ & $13.55-14.5$ & Red sediment & $15,300 \pm 400$ & nd \\
\hline
\end{tabular}

\section{ACKNOWLEDGMENTS}

Thanks are due to James Feather whose queries initiated this study again, to C Hatté for useful comments and suggestions, to C Souprayen for sample preparations, and to J-P Dumoulin and C Moreau for AMS analyses. 


\section{Fontugne}

\section{REFERENCES}

Araujo AGM, Neves WA, Piló LB, Atui JPV. 2005. Holocene dryness and human occupation in Brazil during the "Archaic Gap." Quaternary Research 64(3):298307.

Arnold M, Bard E, Maurice P, Duplessy JC. $1987 .{ }^{14} \mathrm{C}$ dating with the Gif-sur-Yvette Tandetron accelerator: status report. Nuclear Instruments and Methods in Physics Research B 29(1-2):635-45.

Arnold M, Bard E, Maurice P, Valladas H, Duplessy JC. 1989. ${ }^{14} \mathrm{C}$ dating with the Gif-sur-Yvette Tandetron accelerator: status report and study of isotopic fractionation in the sputter ion source. Radiocarbon 31(3): 284-91.

Délibrias G, Guillier MT, Labeyrie J. 1986. Gif natural radiocarbon measurements X. Radiocarbon 28(1):968.

Hatté C, Poupeau J-J, Tannau J-F, Paterne M. 2003. Development of an automated system for preparation of organic samples. Radiocarbon 45(3):421-30.

Hurt Jr WR. 1960. The cultural complexes from the Lagoa Santa Region, Brazil. American Anthropologist 62(4):569-85.

Hurt Jr WR. 1986. The preceramic cultures of Lagoa Santa, some observations. CLIO Archeológica 8:14552.

Hurt WR, Blasi O. 1969. O projeto arqueológico 'Lagoa Santa', Minas Gerais, Brasil (nota final). Arquivos do Museu Paranaense (N.S.) Arqueologia 4:1-63.

Laming-Emperaire A. 1976. Le plus ancien peuplement de l'Amérique. Bulletin de la Société préhistorique française 73:280-8.

Laming-Emperaire A. 1979. Missions archéologiques franco-brésiliennes de Lagos Santa, Minas Gerais, Brésil - Le grand abri de Lapa Vermelha (P.L.). Revista de Pré-história 1:53-89.

Laming-Emperaire A, Prous A, Moraes AV, Beltrão MC. 1975. Grottes et Abris de la Region de Lagoa Santa, Minas Gerais, Brésil: premier rapport de la Mission archéologique franco-brésilienne de Lagoa Santa. Cahiers d'archéologie d'Amérique du Sud 1. Paris: École pratique des hautes étude. $185 \mathrm{p}$.

Lund PW. 1842. Carta escripta de Lagôa Santa ao senhor primeiro secretário do Instituto. Revista do Instituto Histórico e Geográfico Brasileiro 4:30-87.

Lund PW. 1844. Carta escripta de Lagoa Santa a 21 de abril de 1844. Revista do Instituto Histórico e Geográfico Brasileiro 6:334-42.

Mello e Alvim CM. 1977. Os antigos habitantes da área arqueológica de Lagoa Santa, MG. Arquivos do Museu Nacional de História Natural da Universidade Federal de Minas Gerais 2:119-74.

Neves WA, Powell JF, Prous A, Ozolins EG, Blum M. 1999. Lapa Vermelha IV hominid 1: morphological affinities of the earliest known American. Genetics and Molecular Biology 22(4):461-9.

Prous A. 1980. Fouilles du grand abri de Santana do Riacho (Minas Gerais, Brésil). Journal de la Société des Américanistes 67:163-83.

Prous A, Fogaça E. 1999. Archaeology of the Pleistocene-Holocene boundary in Brazil. Quaternary International 53-54:21-41.

Reimer PJ, Baillie MGL, Bard E, Bayliss A, Beck JW, Bertrand CJH, Blackwell PG, Buck CE, Burr GS, Cutler KB, Damon PE, Edwards RL, Fairbanks RG, Friedrich M, Guilderson TP, Hogg AG, Hughen KA, Kromer B, McCormac G, Manning S, Bronk Ramsey C, Reimer RW, Remmele S, Southon JR, Stuiver M, Talamo S, Taylor FW, van der Plicht J, Weyhenmeyer CE. 2004. IntCal04 terrestrial radiocarbon age calibration, 0-26 cal kyr BP. Radiocarbon 46(3):1029-58.

Stuiver M, Polach HA. 1977. Discussion: reporting of ${ }^{14} \mathrm{C}$ data. Radiocarbon 19(3):355-63.

Stuiver M, Reimer P. 1993. Extended ${ }^{14} \mathrm{C}$ data base and revised CALIB $3.0{ }^{14} \mathrm{C}$ age calibration program. $R a$ diocarbon 35(1):215-30. 